\title{
43. Ethan Brown - the protein revolutionary
}

\section{Geoffrey Heal}

Meat, and beef in particular, is something that the environmental movement loves to hate. Cattle produce methane, a powerful greenhouse gas, and need vast areas for grazing, much of which is created by clearing forests, in the process destroying habitat and releasing stored carbon from the soil into the air. In recent years, the animal rights movement has added its growing voice to the anti-meat clamor. However, protein is an essential element of our diets, and meat is a tasty, convenient and culturally sanctified way of delivering it. Displacing animal products from diets seemed a pipe dream.

No more. Beyond Meat and Impossible Foods (and others) are transforming protein possibilities, providing foods that look and taste like meat, and have the same protein content, but are based entirely on plants. With sales growing rapidly, Beyond Meat has a stock market value of over $\$ 5$ billion, having peaked at near $\$ 12$ billion.

Ethan Brown, Beyond Meat's founder, is a passionate vegan, and deeply concerned about climate change. Ending the use of animal protein speaks to both these issues: it ends factory farming and the associated animal suffering, and removes a major source of greenhouse gases. He was driven to found Beyond Meat by a sense of obligation to contribute on these issues: he felt his life would be a lie unless he could resolve the conflict between eating well and doing well by the planet.

Brown emphasizes that Beyond Meat's products are meat, but plant-based meat rather than animal-based meat. As he explains, animals are bioreactors that take proteins from plants and rearrange them into muscle tissue: Beyond Meat's technology also takes proteins from plants and rearranges them into something very close to muscle tissue, and does this rearrangement at a vastly lower environmental cost. His aim is to make products that are indistinguishable from animal meat, but are healthier, providing protein without the harmful chemicals in red meat, such as cholesterol, and with more fiber. Beyond Meat has signed up a number of elite athletes who eat only its products, and Brown dreams of making the National Basketball Association (NBA) vegan! For 2 million years, humans and their predecessors took protein from animals, and 
Brown wants our generation and his company to break that tradition and free us from dependence on animal meat.

Little in Brown's background makes him an obvious choice for such a pivotal role in human history. His father, a professor at the University of Maryland, also owned a dairy farm, where Brown spent much of his time as a youth. After graduating, Brown worked in cleantech, ${ }^{1}$ developing fuel cells, and after completing an MBA at Columbia went back into cleantech. But all this time he was thinking about the conflict between eating well and doing well by the planet, and he began his venture into commercializing this concern by importing textured soy protein from Taiwan and selling it to Whole Foods. Then he learned about research at the University of Missouri on making protein from plants take the form of meat. He licensed this research and developed it further at the University of Maryland, and this is what in 2009 led to Beyond Meat. For the first few years he funded this venture himself, even selling his home to raise money, and then venture capital firm Kleiner Perkins and other outsiders - including Bill Gates - invested.

Ethan Brown did in fact bring several important qualities to the problem of replacing meat. One was an obsession with solving this problem, and a willingness to do whatever was needed. He is an intense and focused person, and the focus is on replacing animal meat. A second was a good enough education in science and technology to understand the scientific issues involved, and the third was a business background: as an MBA student at Columbia, he took a course on starting a new venture. Obsession, focus, understanding, business skills, and of course a receptive market: these were enough to generate the explosion of creativity that is Beyond Meat. Their research labs are in Manhattan Beach, California, and he has christened their research program the Manhattan Beach Project, riffing off the development of the atomic bomb during World War II to give a sense of urgency and importance. The Manhattan Beach Project could change the world as much as the Manhattan Project did to produce the first nuclear weapons, though in a more constructive direction.

It is worth emphasizing the receptiveness of the market for Beyond Meat and its competitors: in both the US and Europe, vegetarian and vegan diets grew rapidly in popularity from around 2000 on. Millennials and subsequent generations are increasingly "flexitarian," that is, they are reducing the amount of meat they eat and moving to largely vegan diets. The environmental community is also increasingly aware of the environmental impact of food choices and looking to minimize these. Both groups form natural markets for Beyond Meat's products.

Beyond Meat is now well established, with its products available at most major fast food chains and many retail grocery outlets. But it has to face serious competitors. Impossible Foods is one, targeting the same market sector. Good Catch aims to do for fish what Beyond Meat has done for meat. Perhaps more 
threatening, Tyson Foods is now selling plant-based chicken substitutes, and could easily move into other meats too. So too could several other large food conglomerates, so establishing a brand name and market position is key to Beyond Meat's long-run financial success.

Both Beyond Meat and Impossible Foods are planning to sell their products in China. This makes strategic sense: it's a huge meat market and also has an indigenous tradition of plant-based meat substitutes, many of which have been sold in Chinese restaurants in the West for many years. Indeed, Ethan Brown's first venture was importing textured soy protein from Taiwan. But China already has domestic competitors to the US start-ups, including Whole Perfect Foods and Zhenmeat, so establishing a profitable presence in China will be a challenge for the US companies.

In terms of Brown's original goals of reducing the animal welfare and environmental impacts of our food, the company has already succeeded. According to a study commissioned by Beyond Meat with the Center for Sustainable Systems at the University of Michigan, a plant-based burger generates 90 percent less greenhouse gas emissions, requires 45 percent less energy, has 99 percent less impact on water scarcity, and 93 percent less impact on land use than a quarter-pound of traditional U.S. beef. And in 2013, People for the Ethical Treatment of Animals (PETA) named Beyond Meat its company of the year. Brown and his colleagues have shown that plant-based protein can sell and be profitable, bringing about an irreversible change in the food industry.

\section{NOTE}

1. Technologies that either reduce or optimize the use of natural resources whilst simultaneously reducing the negative effect that technology has on the plant and its ecosystems. 